\title{
Challenges faced by entrepreneurs and the performance of small and medium scale (SMEs) In Nigeria: An Intellectual capital issue
}

\author{
Omolomo Odunayo Tobora \\ Faculty of Economics and Business, Universiti Malaysia Sarawak, \\ 94300 Kota Samarahan, Sarawak, Malaysia \\ E-mail address: odunayophd@yahoo.ca
}

\begin{abstract}
An entrepreneur is one who contributes significantly more than others to the economy by virtue of innovation and realizing new combinations. Which involve creation of a new product, a new method of production, the opening of a new market, the capture of a new source of supply, or a new organization of industry. Entrepreneurship of SMEs performance in knowledge -based economy. In addition, this study also explores the challenges which are facing small and medium enterprises (SMEs) in Nigeria. The significance of the study will add to the knowledge about current issues relating to SMEs in Nigeria The main thrust of this study is challenging which face Entrepreneur of small and medium scale enterprises (SMEs) on business performance in Nigeria.
\end{abstract}

Keywords: Entrepreneur; Business performance; SMEs; Enterprises; Nigeria

\section{INTRODUCTION}

Entrepreneurship is not a science that can be perfectly defined, but rather an amalgamation or medley of art and science, which displays itself with a combination of factors in a range of different settings, contexts, industries, countries and times. Some of the developmental definitions of entrepreneurship will be explored in this study so as to capture the complexities. Definitions of entrepreneurship According to Kirzner $(1973,1997)$ lay specific emphasis on innovation, identification of opportunities, wealth creation, consequences for the economy, and the entrepreneur as the main actor in the entrepreneurial process will be adopted as the working definitions for this paper. In high-income countries, formal SMEs contribute to 50 percent of GDP on average. Furthermore, in many economies the majority of jobs are provided by SMEs. In OECD countries, for example, SMEs with less than 250 employees employ two-thirds of the formal work force, this was asserted by Beck (2005). Using countrylevel data, According to Ayyagari (2008) estimate that, on average, SMEs account for close to 60 percent of employment in the manufacturing sector. According to SME Performance Review (2009), between 2002 and 2008, the numbers of jobs in SMEs increased at an average annual rate of 1.9 percent, while the number of jobs in large enterprises increased by only 0.8 percent. In absolute numbers, 9.4 million jobs were created in the SME sector in EU-27 between 2002 and 2008. Also, it is often argued that SMEs are more innovative than larger firms Adeyemi (2007) In developed countries, SMEs commonly follow "niche strategies," using high product 